\title{
Two-week pulsatile gonadotropin releasing hormone infusion unmasks dual (hypothalamic and Leydig cell) defects in the healthy aging male gonadotropic axis
}

\author{
Thomas Mulligan, Ali Iranmanesh ${ }^{1,3}$, Roger Kerzner, Laurence W Demers ${ }^{2}$ and Johannes D Veldhuis ${ }^{3,4}$ \\ McGuire VA Medical Center, Richmond, Virginia, USA, ${ }^{1}$ Salem VA Medical Center, Salem, Virginia, USA, ${ }^{2}$ Pennsylvania State University, Hershey, \\ Pennsylvania, USA, ${ }^{3}$ University of Virginia Health Sciences Center, Charlottesville, Virginia, USA and ${ }^{4}$ National Science Foundation Center for \\ Biological Timing
}

(Correspondence should be addressed to T Mulligan, 1201 Broad Rock Blvd, Richmond, Virginia 23249, USA;

Email: Mulligan.Thomas_M@Richmond.VA.GOV)

\begin{abstract}
Objective: To examine the possibility that lower serum bioavailable testosterone concentrations, without increased LH release, in healthy older men, reflects hypothalamic GnRH deficiency. Design: We used a randomized, double-blind, placebo-controlled design.

Methods: We treated each of five young (ages 20-34 years) and five older (ages 60-78 years) men with 2 weeks of randomized infusions of saline or pulsatile $\mathrm{GnRH}(100 \mathrm{ng} / \mathrm{kg}$ i.v. every $90 \mathrm{~min})$.

Results: At baseline (saline infusion), older men had more LH pulses (young compared with old, $10 \pm 0.6$ compared with $15 \pm 1, P=0.0026)$ per $24 \mathrm{~h}$, reduced fractional LH pulse amplitude (219 $\pm 17 \%$ compared with $167 \pm 40 \%, P=0.0376)$, and more disorderly hormone release as judged by approximate entropy (ApEn) (LH, $P \leq 0.0001$; testosterone, $P \leq 0.0047$ ). In response to pulsatile i.v. GnRH infusions, serum 24-h LH concentrations (measured by immunoradiometric assay (IRMA)), increased equivalently in young and older men (to $7.3 \pm 1.2$ and $7.2 \pm 1.8 \mathrm{IU} / \mathrm{l}$ respectively). GnRH treatment also normalized LH pulse frequency and amplitude, ApEn, and plasma biologically active LH (pooled) concentrations. In contrast, 24-h testosterone concentrations failed to increase equivalently in older men (young compared with old, $869 \pm 88$ compared with $517 \pm 38 \mathrm{ng} / \mathrm{dl}$, $P=0.0061)$, reflecting lower testosterone peak maxima $(995 \pm 108$ compared with $583 \pm 48 \mathrm{ng} / \mathrm{dl}$, $P=0.0083)$ and interpeak nadirs $(750 \pm 87$ compared with $427 \pm 26 \mathrm{ng} / \mathrm{dl}, P=0.0073)$.

Conclusions: We have demonstrated that, in older men, successful reconstitution of 24-h pituitary (bioactive) LH output and pulsatile (IRMA) LH release patterns could be achieved by a fixed exogenous GnRH pulse signal, thereby implicating altered endogenous hypothalamic GnRH release in the relative hypogonadotropism of aging. The failure of testosterone concentrations to increase concomitantly points to a simultaneous Leydig cell defect. We conclude that aging in men is marked by a dual defect in the central nervous system-pituitary-Leydig cell axis.
\end{abstract}

European Journal of Endocrinology 141 257-266

\section{Introduction}

Multiple regulatory factors (e.g., sex steroids, polysynaptic neuronal inputs) coordinate hypothalamic secretion of bursts of gonadotropin-releasing hormone $(\mathrm{GnRH})$ in women and men (1). Pulsatile release of GnRH into the hypothalamic-pituitary portal microcirculation in turn stimulates (feedforward) episodes of pituitary secretion of luteinizing hormone (LH). Intermittent secretion of LH into the systemic circulation correspondingly drives pulsatile gonadal production of testosterone in men (2). Biologically active testosterone in the plasma completes the feedback control loop, via time-lagged inhibition of GnRH and $\mathrm{LH}$ secretion $(3,4)$.
The negative impact of aging on the male hypothalamic-pituitary-gonadal axis is important, because diminished sex-steroid secretion in men is accompanied by decreased muscle mass and strength, reduced bone mineral density and greater risk of hip fracture, loss of sexual interest, increased risk of coronary artery disease, and impaired psychological well-being and spatial cognition (5-9). Mechanistically, attenuation of gonadal testosterone secretion could be caused by disrupted feedforward or feedback interactions among the key control sites within the male reproductive axis, viz. the hypothalamus, pituitary gland, or Leydig cells. Based on available indirect clinical data $(10-12)$, we postulated that diminished hypothalamic GnRH secretion in healthy older men 
gives rise mechanistically to the reduced pituitary LH and Leydig cell testosterone secretion.

To test the hypothesis of diminished brain $\mathrm{GnRH}$ secretion in older men, we administered synthetic GnRH or saline, in randomized order, as pulsatile i.v. infusions for 2 weeks, to young and to older individuals at a weight-adjusted GnRH dose that normalizes LH secretion in hypogonadotropic men (13). On day 14 of GnRH or saline treatment, we compared individual and joint LH and testosterone release as quantitated by validated pulse and entropy analyses in older and young individuals.

\section{Methods}

This study was approved by the University of Virginia Human Investigation Committee. We studied healthy young ( $n=5$, age $20-34$ years) and older $(n=5$, age 60 78 years) men, who had no acute or chronic illness, ingested no drugs or medications, were non-smokers, were within $20 \%$ of ideal body weight, and had not undertaken any transmeridian travel in the past 2 weeks.

After giving written informed consent, participants were connected to a pocket-sized GnRH infusion pump (Ferring Laboratories) with an i.v. catheter placed in a forearm vein. Volunteers then received 2 weeks of either saline or $\mathrm{GnRH}$ (administered as $100 \mathrm{ng} / \mathrm{kg}$ i.v. bolus injections every $90 \mathrm{~min}$ ). The study design was a randomized, double-blind, cross-over trial of saline compared with GnRH. On day 14 of $\mathrm{GnRH}$ or saline infusions, the men spent $36 \mathrm{~h}$ in the General Clinical Research Center. The first $12 \mathrm{~h}$ overnight were to acclimate the individual to the setting. During the next $24 \mathrm{~h}$ (0800 $\mathrm{h}$ until $0800 \mathrm{~h}$ the following morning), while the pulsatile GnRH or saline infusion continued, volunteers underwent venous sampling every $10 \mathrm{~min}$ (145 samples). Blood samples were allowed to clot at room temperature and the sera were frozen at $-20{ }^{\circ} \mathrm{C}$ for later assay of $\mathrm{LH}$ and testosterone.

We performed serum LH assays in duplicate via a fully automated robotics system, using a two-site monoclonal immunoradiometric assay (IRMA, Nichols Laboratory, San Juan Capistrano, CA, USA). The sensitivity of the LH IRMA was 0.10 IU/l (First International Reference Preparations). The inter- and intra-assay coefficients of variation were $<5.5 \%$. Serum total testosterone measurements were performed in duplicate on each sample, using an RIA (Diagnostic Products, Los Angeles, CA, USA) with an assay sensitivity of $20 \mathrm{ng} / \mathrm{dl}$ and inter- and intra-assay coefficients of variation of $<10 \%$. Bioavailable testosterone, biologically active LH, and inhibin B concentrations in 24-h serum pools were assayed exactly as described previously (14-16). FSH, prolactin, IGF-I, DHEA and estradiol were also measured.

For pulse analysis of the LH and testosterone time series, we used Cluster analysis, as a model-free discrete peak detection algorithm, as described previously (17). Approximate entropy (ApEn) was applied to quantitate the relative disorderliness of the LH (or testosterone) release process, as previously reported (18).

For comparisons of the effect of GnRH or saline within either the young or older cohorts, we used the Wilcoxon two-tailed matched-pairs signed-ranks test. For comparisons between the young and older men, we used the unpaired Mann-Whitney $U$ (rank sum) test. $P<0.05$ was construed as statistically significant.

\section{Results}

Illustrative serum concentration time series for $\mathrm{LH}$ (IRMA) and total testosterone (RIA) are presented in Figs 1 and 2. During the control period (saline), young and older subjects had no significant differences in their mean 24-h serum LH concentration by IRMA (young compared with older, $3.2 \pm 0.56$ compared with $3.2 \pm$ $0.40 \mathrm{IU} / \mathrm{l}$ ) or in total testosterone concentrations (young compared with older, $460 \pm 39.8$ compared with $397 \pm$ $35.0 \mathrm{ng} / \mathrm{dl}$ ). However, control (pre-GnRH) bioactive LH concentrations (young compared with older, $28 \pm 13$ compared with $15 \pm 2.7 \mathrm{IU} / \mathrm{l}$ ) and bioavailable testosterone concentrations tended to be lower in older men (young compared with older, $383 \pm 13$ compared with $181 \pm 16 \mathrm{ng} / \mathrm{dl}$ ). Findings for other hormones (FSH, prolactin, and dihydroepiandrosterone) are outlined in Table 1.

By Cluster analysis, older men had more frequent peaks of serum LH (young compared with older, $10 \pm$ 0.6 compared with $15 \pm 1, P=0.0026)$ per $24 \mathrm{~h}$, and reduced serum LH peak amplitudes (young compared with older, $219 \pm 17 \%$ compared with $167 \pm 40 \%$, $P=0.0376)$.

Approximate entropy (ApEn) of 24-h LH release in the control session was markedly increased, indicating greater disorderliness, in the older men (young compared with older, $0.699 \pm 0.076$ compared with $1.523 \pm 0.063, P=0.0001)$, as was the ApEn for $24-\mathrm{h}$ testosterone release (young compared with older, $1.399 \pm 0.080$ compared with $1.710 \pm 0.009, P=$ 0.0047). Cross-ApEn of joint LH-testosterone synchrony over 24-h was also higher in the older individuals (young compared with older, $1.351 \pm 0.119$ compared with $2.010 \pm 0.050, P=0.0009$ ).

After 2 weeks of pulsatile i.v. GnRH infusions, mean serum 24-h LH concentrations increased equivalently in young and older men (by IRMA, to $7.3 \pm 1.2$ compared with $7.2 \pm 1.8 \mathrm{IU} / \mathrm{l})$. Bioactive $\mathrm{LH}$ also increased statistically similarly in both age groups (young compared with older, $57 \pm 13$ compared with $31 \pm 6.6 \mathrm{IU} / \mathrm{l}, P=\mathrm{NS}$ ). Cluster-identified LH pulse frequency and amplitude, and ApEn, became statistically identical in the young and older men (Table 2). In contrast, serum (24-h mean) total testosterone concentrations with $\mathrm{GnRH}$ treatment increased less in older men (Fig. 3), because of lower 24-h serum testosterone peak areas, peak maxima, and interpeak nadirs (Table 2). In addition, the relationship between incremental serum 

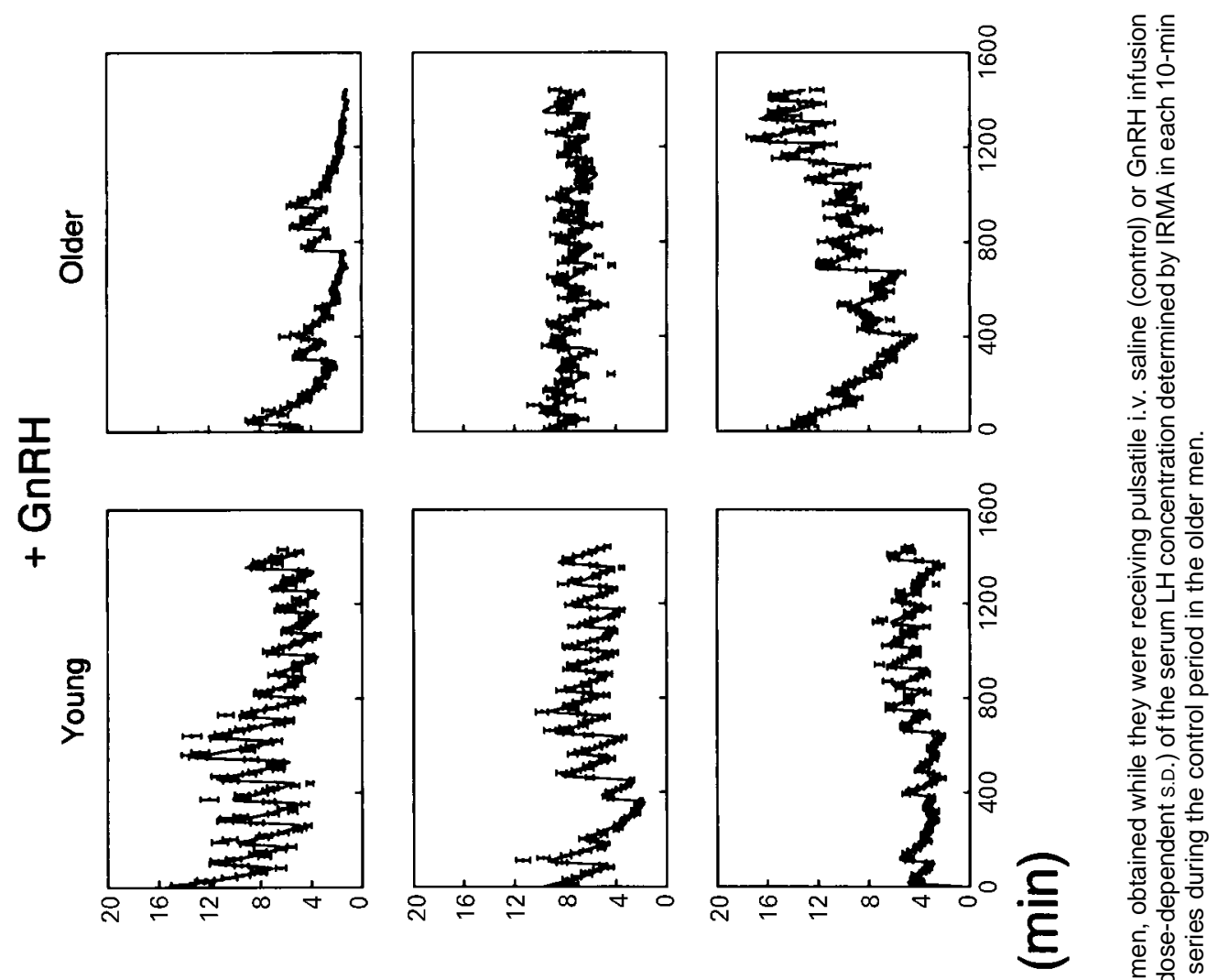

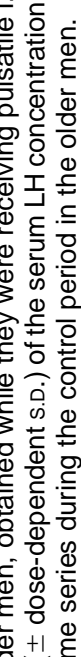

(U) $\quad \frac{\overline{0}}{2}+\frac{\Phi}{\circ}$
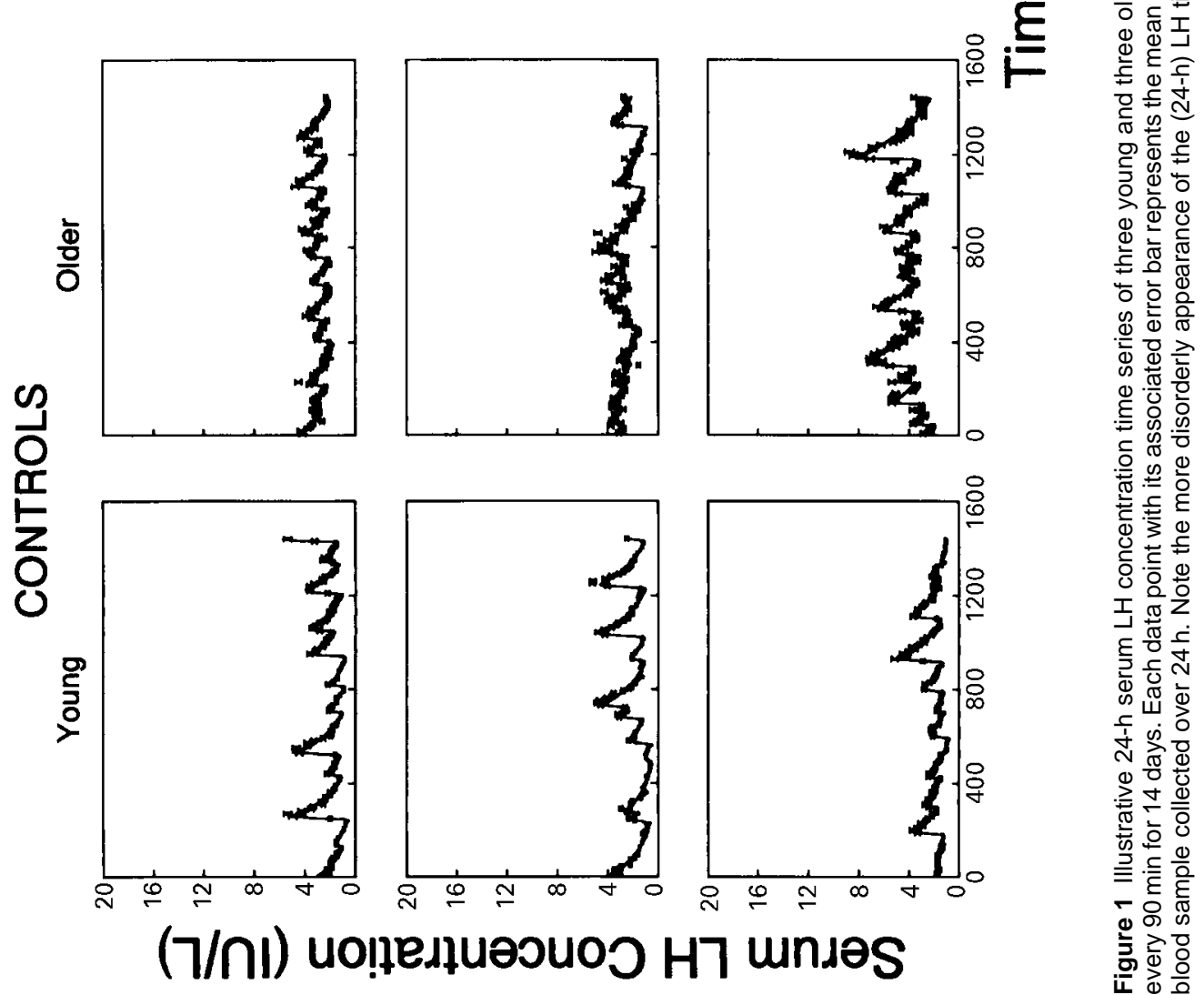

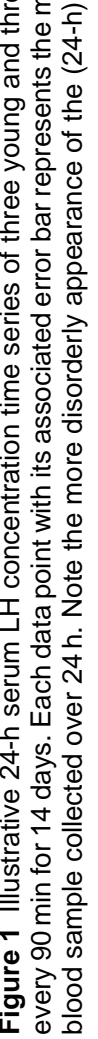



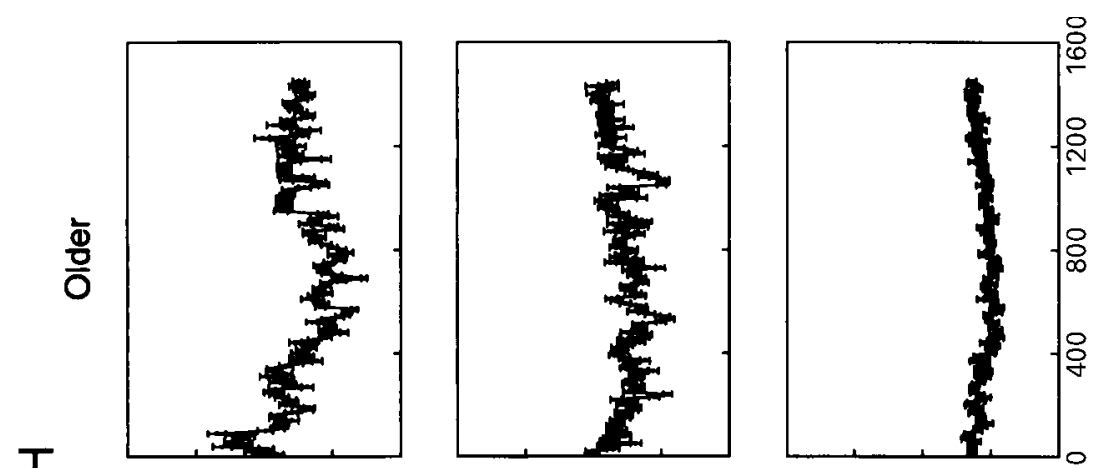

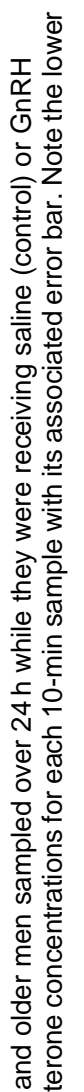
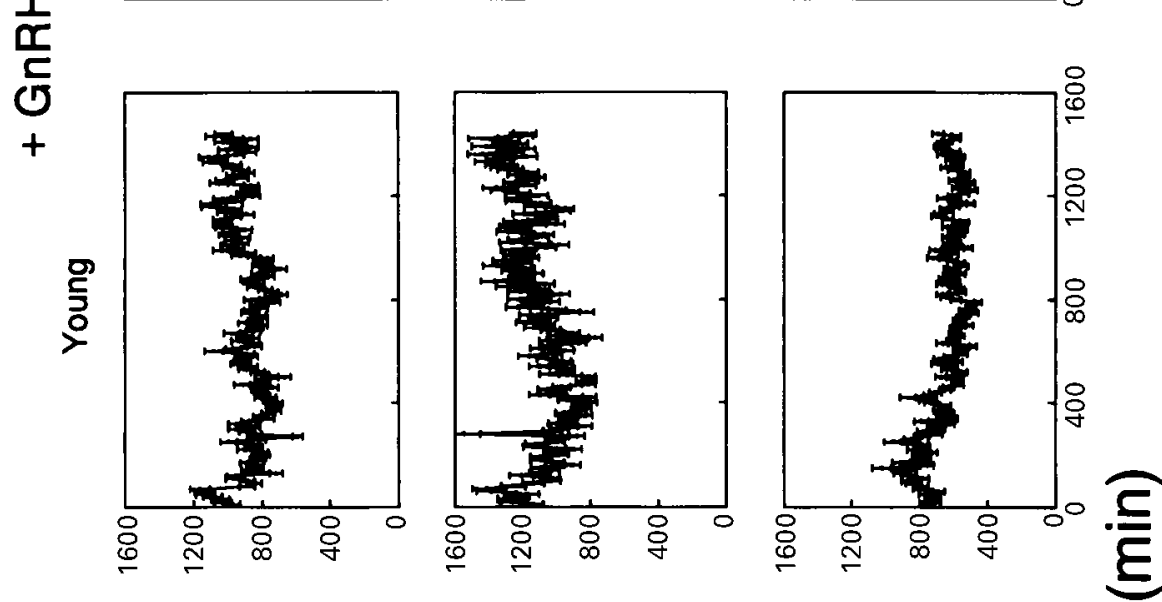

E
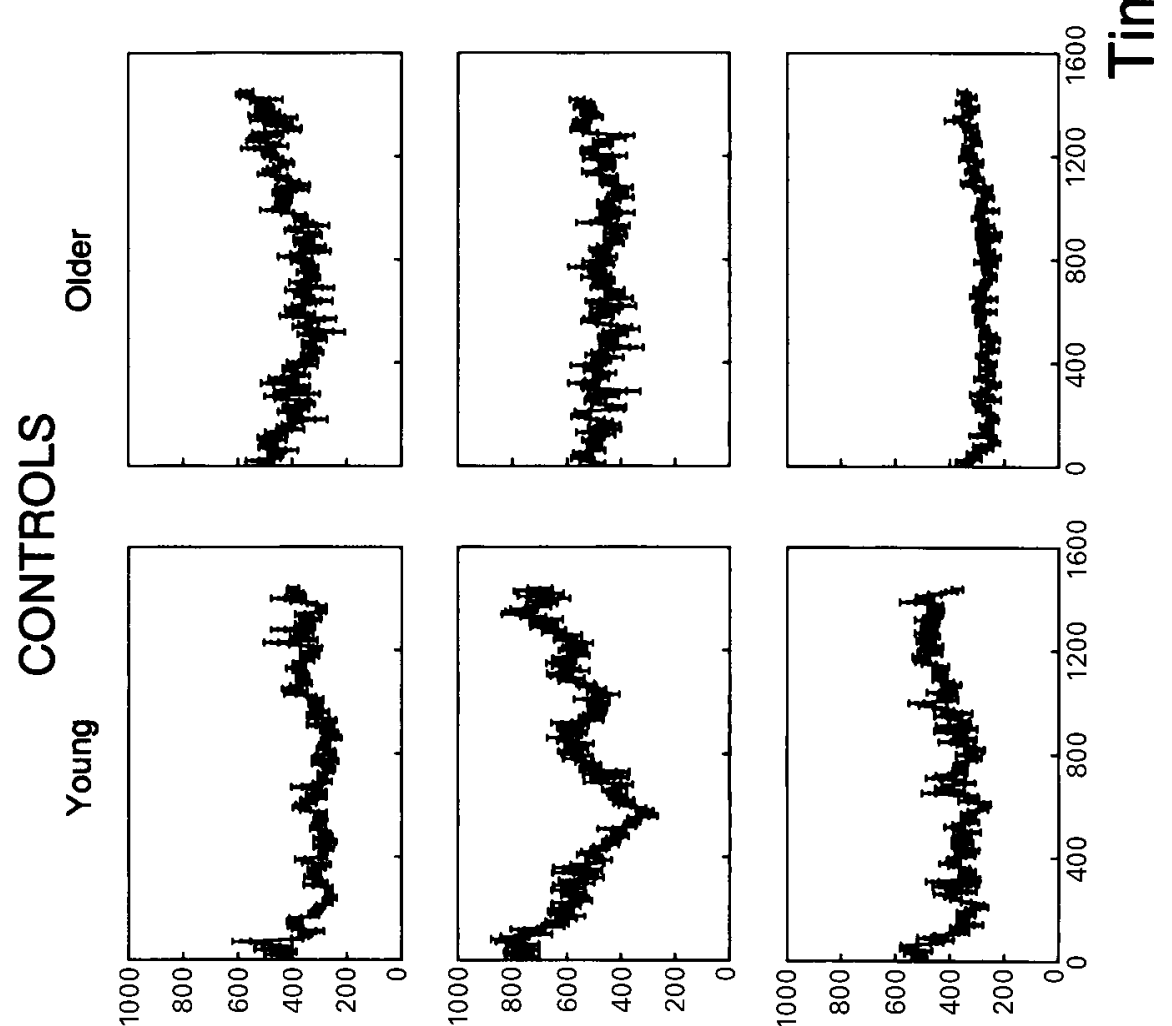

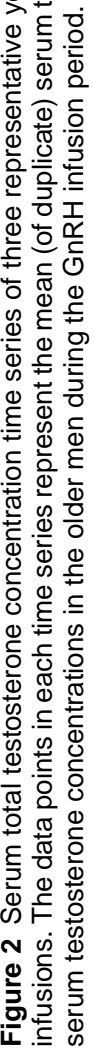

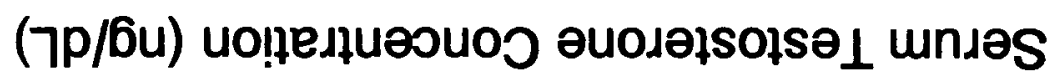

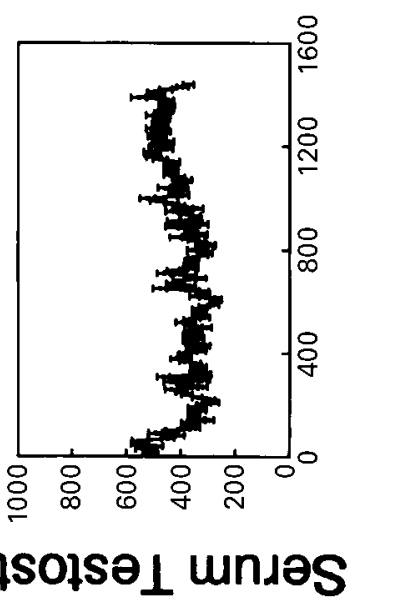


Table 1 Mean ( \pm S.E.M.) hormone concentrations during control or GnRH infusions in young $(n=5)$ and older $n=5)$ men.

\begin{tabular}{|c|c|c|c|c|c|c|}
\hline \multirow[b]{2}{*}{ Hormone } & \multicolumn{3}{|c|}{ Control period } & \multicolumn{3}{|c|}{ GnRH period } \\
\hline & Young & Older & $P$ value & Young & Older & $P$ value \\
\hline $\mathrm{FSH}(\mathrm{IU} / \mathrm{I})$ & $4.8 \pm 2.1$ & $4.0 \pm 1.1$ & NS & $5.4 \pm 1.4$ & $6.4 \pm 2.5$ & NS \\
\hline Prolactin $(\mu \mathrm{g} / \mathrm{dl})$ & $8.7 \pm 0.89$ & $4.9 \pm 0.62$ & 0.0074 & $13.7 \pm 1.7$ & $6.3 \pm 1.2$ & 0.0067 \\
\hline IGF-I $(\mu \mathrm{g} / \mathrm{I})$ & $249 \pm 29.1$ & $123 \pm 33.4$ & 0.022 & $325 \pm 50$ & $137 \pm 31$ & 0.013 \\
\hline DHEA $(\mu \mathrm{g} / \mathrm{dl})$ & $251 \pm 20.5$ & $118 \pm 36$ & 0.013 & $306 \pm 35.6$ & $128 \pm 48.3$ & 0.018 \\
\hline Inhibin B concn (pg/ml) & $78 \pm 6.4$ & $77 \pm 3.4$ & NS & $69 \pm 3.0$ & $65 \pm 2.4$ & NS \\
\hline
\end{tabular}

concn, concentration.

LH concentrations and increased testosterone concentrations was markedly blunted in the older men (Fig. 4). Bioavailable testosterone also failed to increase in older men receiving GnRH pump treatment $(P=0.0026)$. Specifically, the values in young men increased to $669 \pm 104 \mathrm{ng} / \mathrm{dl}$ compared with $268 \pm 31 \mathrm{ng} / \mathrm{dl}$ in older volunteers (Fig. 5). Confirming Leydig cell failure in the older men, serum estradiol concentration also did not increase in the older men while they were receiving GnRH (Fig. 6). Serum prolactin and insulin-like growth factor-I (IGF-I) concentrations similarly failed to increase significantly in the older men (Figs 7,8 ).

There was also a markedly blunted relationship between the increase in serum total testosterone concentrations and changes in serum IGF-I concentrations in the older men (Fig. 9). In particular, as the serum total testosterone concentration increased during GnRH infusion in young men, so did the serum IGF-I concentration. In contrast, there was no such positive association in the older men. Neither age group showed greater (pooled 24-h) serum inhibin B concentrations during GnRH infusions (Table 1).

\section{Discussion}

The present clinical investigation is, to our knowledge, the first in vivo assessment of the human pituitaryLeydig cell axis in healthy older men using a short-term (2-week) pulsatile i.v. GnRH 'clamp' technique to impose an experimentally uniform (exogenous) $\mathrm{GnRH}$ pulse stimulus. This clinical strategy serves to isolate the pituitary-Leydig cell unit under an unvarying (extrinsically controlled) hypothalamic peptide releasingfactor drive, thus eliminating potential confounding influences arising from the unequal hypothalamic $\mathrm{GnRH}$ input in young and older individuals. In this experimental paradigm, we established that aging is not associated with measurably impaired gonadotrope secretion of either biologically active or immunologically reactive $\mathrm{LH}$, when young and older men are given equivalent pulsatile GnRH stimulation. In both young and older men, 2 weeks of i.v. pulsatile $\mathrm{GnRH}$ treatment elicited quantitatively identical 24 -h serum LH concentration profiles, with statistically indistinguishable pulsatile LH output (assessed by Cluster analysis) and orderliness of LH release (quantitated by approximate entropy). The absence of any apparent agerelated deficit in exogenous GnRH-driven immunoreactive (or 24-h pooled bioactive) LH secretion speaks for a preserved pituitary gonadotrope secretory capacity and responsiveness in older men.

Previous investigators have studied the endogenously regulated gonadotrope-Leydig cell axis in older men, but have published conflicting results. Two recent studies evaluating bioactive or immunoreactive LH release after graded submaximal bolus doses of GnRH suggested increased age-related (maximal) LH secretion $(19,20)$. Other reports utilizing a single high(er) dose of GnRH

Table 2 Pulsatile LH and testosterone release during control or $\mathrm{GnRH}$ infusions in young $(n=5)$ and older $(n=5)$ men.

\begin{tabular}{|c|c|c|c|c|c|c|}
\hline & \multicolumn{3}{|c|}{ Control period } & \multicolumn{3}{|c|}{ GnRH period } \\
\hline & Young & Older & $P$ value & Young & Older & $P$ value \\
\hline \multicolumn{7}{|l|}{ LH } \\
\hline Pulse frequency (1/24h) & $10 \pm 0.5^{*}$ & $15 \pm 1.0$ & 0.0026 & $15 \pm 0.7$ & $13 \pm 0.9$ & NS \\
\hline Pulse amplitude (\%) & $219 \pm 17$ & $167 \pm 40$ & 0.0376 & $168 \pm 11$ & $153 \pm 10$ & NS \\
\hline ApEn & $0.699 \pm 0.076$ & $1.523 \pm 0.063$ & 0.0001 & $1.296 \pm 0.067$ & $1.387 \pm 0.173$ & NS \\
\hline \multicolumn{7}{|l|}{ Testosterone } \\
\hline Pulse area (ng/dl × min) & $6239 \pm 1247$ & $3633 \pm 608$ & NS & $9105 \pm 609$ & $5478 \pm 1324$ & 0.00375 \\
\hline Pulse height (ng/dl) & $508 \pm 33.5$ & $447 \pm 39.4$ & NS & $995 \pm 108$ & $583 \pm 48.2$ & 0.0083 \\
\hline Interpeak nadir (ng/dl) & $380 \pm 28.2$ & $331 \pm 25.0$ & NS & $750 \pm 86.7$ & $427 \pm 26$ & 0.0073 \\
\hline ApEn & $1.399 \pm 0.080$ & $1.710 \pm 0.009$ & 0.0047 & $1.595 \pm 0.069$ & $1.671 \pm 0.077$ & NS \\
\hline
\end{tabular}

ApEn, approximate entropy; higher values denote more disorderly hormone release. 


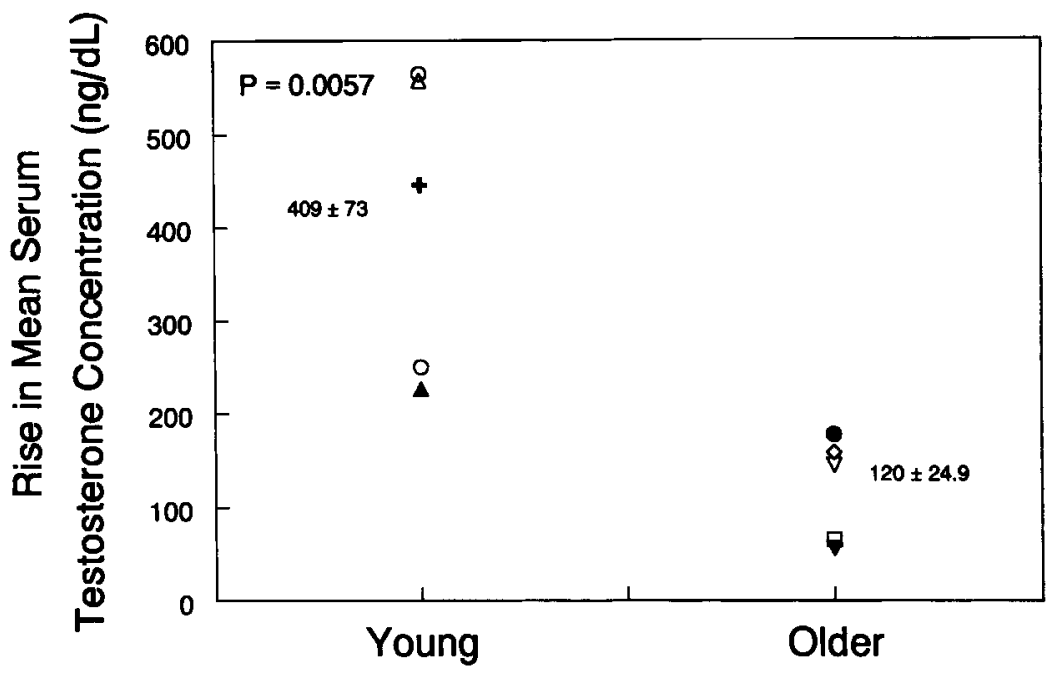

Figure 3 Comparison of the increments $(\mathrm{GnRH}$ treated minus control) in mean (24-hr) serum (total) testosterone concentrations in five individual young and five individual older men while they were receiving a 2-week pulsatile i.v. GnRH infusion. Note the much smaller increment in mean serum testosterone concentrations in the older men. Values are the mean \pm S.E.M., and the $P$ value denotes the non-parametric group (young compared with older) comparison.

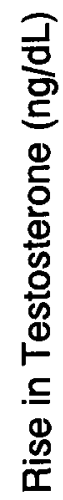

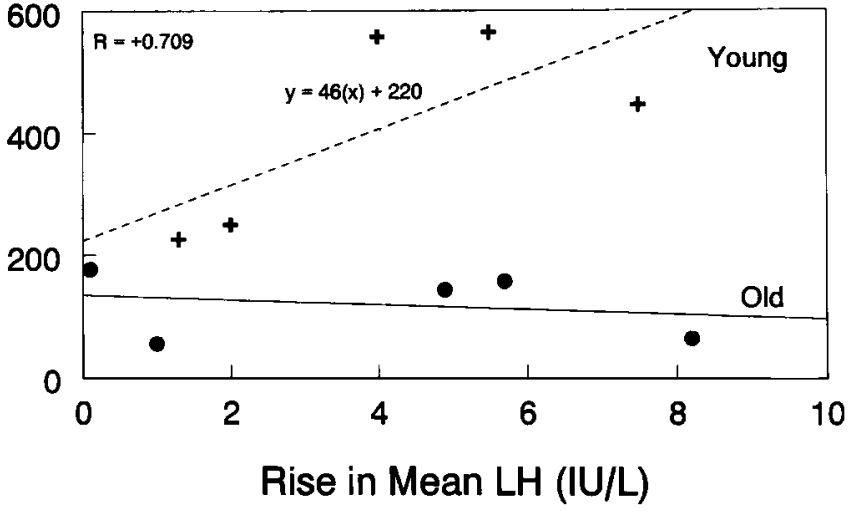

Figure 4 Comparison of the relative increase (increment) in the mean (24-h) serum testosterone concentration for a given increment in the mean (24-h) serum LH concentration in young and older men. Note the marked blunting of the LH-driven testosterone increment in the older men. Equation and $R$ value are for the linear regression (dotted line) of LH increase on testosterone increment in young men $(P=$ NS in older men, (solid line)).

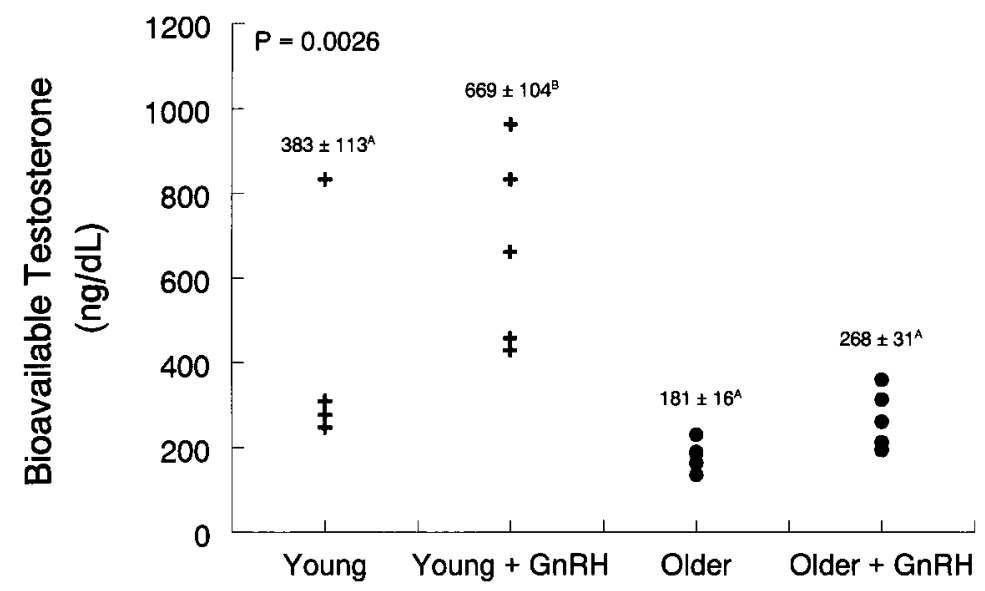

Figure 5 Serum (pooled 24-h) bioavailable testosterone concentrations in young and older men during control (saline) or pulsatile GnRH infusions. The $P$ value was determined by ANOVA; different superscripts denote significantly different treatment means ( \pm S.E.M.). 
Figure 6 Serum (pooled 24-h) estradiol concentrations in young and older men during control (saline) or pulsatile GnRH infusions. The $P$ value was determined by ANOVA; different superscripts denote significantly different treatment means ( \pm S.E.M.). Note the attenuated $\mathrm{GnRH}$-driven increase in the serum estradiol concentration in the older men.
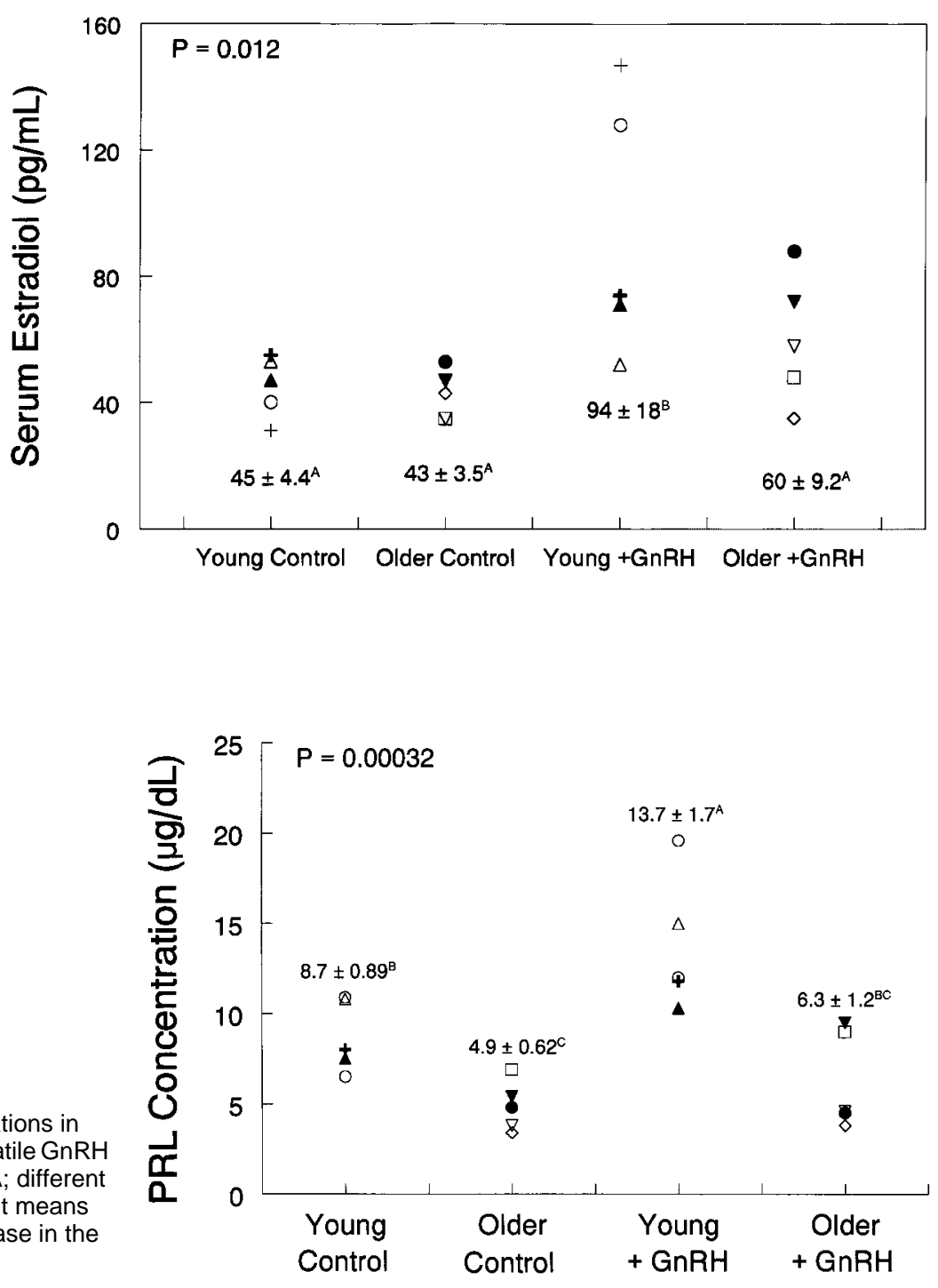

Serum (pooled 24-h) prolactin concentrations in young and older men during control (saline) or pulsatile $\mathrm{GnRH}$ infusions. The $P$ value was determined by ANOVA; different superscripts denote significantly different treatment means ( \pm S.E.M.). Note the attenuated $\mathrm{GnRH}$-driven increase in the serum prolactin concentration in the older men.
Figure 8 Serum (pooled 24-h) IGF-I concentrations in young and older men during control (saline) or pulsatile GnRH infusions. The $P$ value was determined by ANOVA; different superscripts denote significantly different treatment means ( \pm S.E.M.). Note the attenuated GnRH-driven increase in the serum IGF-I concentration in the older men.

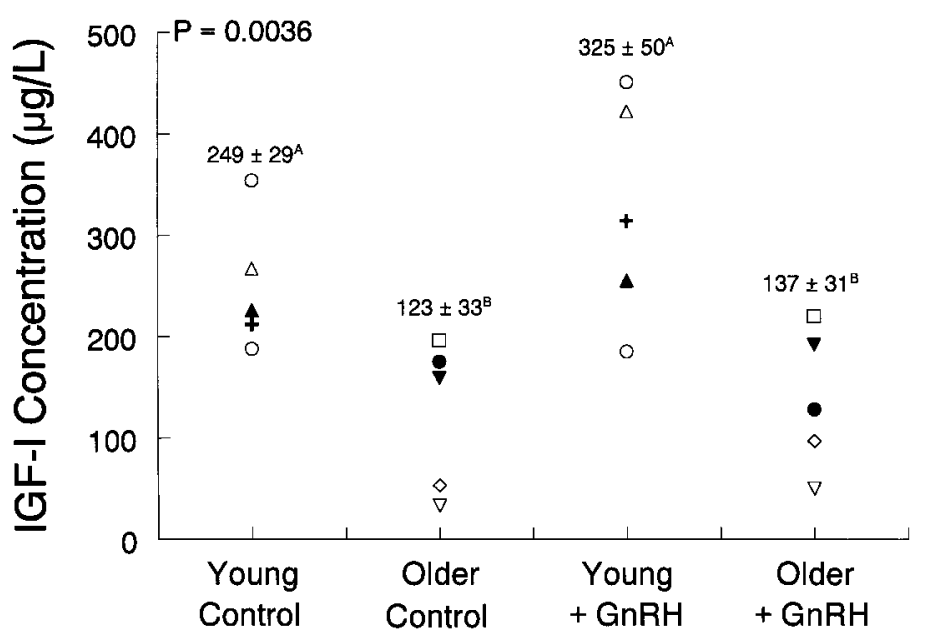




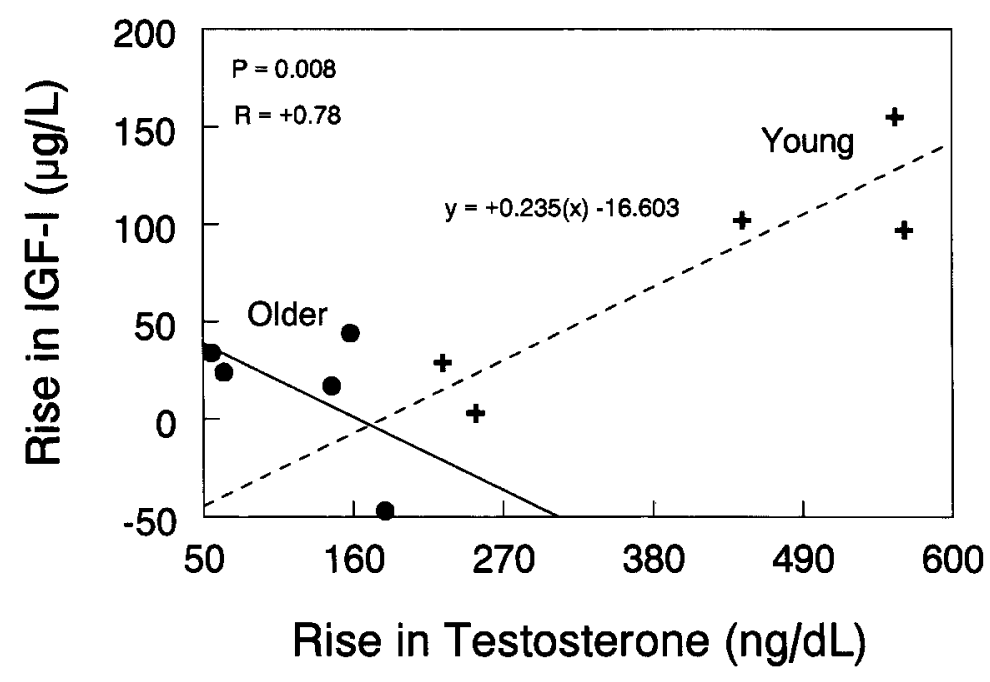

Figure 9 Comparison of the relative increase in the serum (24-h pooled) IGF-I concentration for a given increment in the (24-h mean) serum total testosterone concentration in young (dotted line) and older men (solid line). Note the absence of a positive association between serum testosterone and IGF-I concentrations in older individuals. inferred an age-associated impairment of gonadotrope responsiveness (21-23). However, none of these studies attempted to mimic normal GnRH pulse physiology over a multi-day period, for example by evaluating the pituitary-Leydig unit responses to $>24 \mathrm{~h}$ of nearphysiological i.v. pulses of GnRH in young and in older men. Here, we imposed a 2-week randomized intervention of pulsatile saline or GnRH infusions to achieve uniform and near-physiological hypothalamic decapeptide drive to gonadotrope cells in young and older men. Our finding of statistically comparable entropy of 24-h LH release and LH pulse frequencies and amplitudes under fixed exogenous GnRH stimulation (but not basally under endogenous GnRH drive) in young and older men strongly suggests that alterations in endogenous GnRH release in older men underlie the spontaneous low-amplitude, higher frequency, and more disorderly LH secretion patterns that mark this age group. Indeed, most studies in older men show a relative loss of high-amplitude LH pulses, with or without an evident replacement by higher-frequency low-amplitude peaks (24-26). Our inference that endogenous $\mathrm{GnRH}$ release is attenuated in aging men is consistent with extant animal studies, which have demonstrated diminished brain estrogen-receptor expression in aged male rats (27), ultrastructural changes to $\mathrm{GnRH}$ neurons (28), diminished hypothalamic neuronal oscillations (29), hypothalamic-transplant reversible impotence (30), and attenuated GnRH release in response to excitatory amino acids in older rodents (31).

Despite experimentally induced statistical equalization of pulsatile and entropic LH release patterns and amounts in young and older men, 24-h serum testosterone concentrations and release dynamics remained abnormal in older compared with young adults. The mean (24-h) serum total and bioavailable testosterone concentrations in older men remained diminished during GnRH treatment, as did the maximal amplitude of the individual serum testosterone peaks, their areas, and the interpeak nadirs. These data suggest reduced LH bioactivity, impaired Leydig cell perfusion, a Leydig cell secretory defect, or a combination of these disruptions in aging men. Reduced LH bioactivity on GnRH pump treatment was excluded by in vitro Leydig cell bioassay of 24-h (pooled) serum LH concentrations. However, the last two mentioned putative explanations would concur with prior studies demonstrating decreased testicular perfusion, fewer Leydig cells, diminished responses to human chorionic gonadotropin, and variable steroidogenic defects in older men $(32,33)$. Whereas some studies have suggested decreased basal LH bioactivity/ immunoreactivity ratios in older men to explain the discordance between $\mathrm{LH}$ and testosterone levels (34, 35 ), another report refuted an hypothesis of a gross qualitative difference in the LH isoform profiles in young and older males, but did not eliminate the possibility of reduced LH bioactivity (36). In other investigations, basal LH bioactivity or immunofluorimetric activity was normal in healthy older men $(37,38)$, and only reduced in illness or disease (24). Moreover, LH bioactivity in older men increased normally after interruption of androgen-negative feedback (39), but not during antiestrogen treatment (40). Given impaired gonadal testosterone biosynthesis in aging men and rodents (2, $32,41,42)$, we favor the notion that a steroidogenic defect in Leydig cells accounts for reduced pulsatile testosterone release in older men, despite a GnRHstimulated (and biologically active) LH pulse signal indistinguishable from that achieved in similarly treated young adults. Any putative defect at the Sertoli cell level in aging men could not be evaluated here, given the failure of inhibin B concentrations (of Sertoli cell origin) to increase during $\mathrm{GnRH}$ treatment in either age group. In the present study, basal concentrations of inhibin B were not lower in older men, unlike data from earlier alpha-subunit directed assays $(43,44)$. 
We further noted a positive association between the GnRH-LH-stimulated serum testosterone concentration and the serum IGF-I concentration in the younger men, but a loss of this association in the older men. This observation suggests at least one biological implication at the tissue level of limited testosterone secretory reserve in older individuals.

In summary, the achievement of quantitatively and qualitatively equivalent frequency, amplitude and orderliness of the 24-h serum LH release profiles after 2 weeks of near-physiological pulsatile i.v. GnRH infusions in older men points to GnRH-dependent (hypothalamic) alterations underlying the qualitative disruptions in basal LH secretion otherwise evident in the aging male gonadotropic axis. Our analyses also disclose reduced LH-driven testosterone release in healthy older men, thus indicating a concomitant defect in the Leydig cell of older individuals. In these respects, we suggest that the aging human male and female gonadotropic axes behave mechanistically similarly, with joint hypothalamic-gonadal alterations (45).

\section{Acknowledgements}

This study was supported in part by VA Merit Review grant, 'Mechanisms of the Relative Hypogonadism of Aging', the NSF Center for Biological Timing, NIH P-30 HD 28934 (U54 NICHD Reproduction Research Center), and NIH (NCRR) GCRC Grant No. MO1 RR00847.

\section{References}

1 Urban RJ, Evans WS, Rogol AD, Kaiser DL, Johnson ML \& Veldhuis JD. Contemporary aspects of discrete peak-detection algorithms. I. The paradigm of the luteinizing hormone pulse signal in men. Endocrine Reviews 19889 3-37.

2 Veldhuis JD. Dynamics of the male hypothalamo-pituitarygonadal axis. In Reproductive Endocrinology, pp 409-459. Eds SC Yen \& RB Jaffe. Philadelphia: WB Saunders, 1991.

3 Keenan DM \& Veldhuis JD. A biomathematical model of time-delayed feedback in the human male hypothalamicpituitary-Leydig cell axis. American Journal of Physiology 1998 275 E157-E176.

4 Mulligan T, Iranmanesh A, Johnson ML, Straume M \& Veldhuis JD. Aging alters feedforward and feedback linkages between LH and testosterone in healthy men. American Journal of Physiology 199742 R1407-R1413.

5 Greenspan SL, Oppenheim DS \& Klibanski A. Importance of gonadal steroids to bone mass in men with hyperprolactinemic hypogonadism. Annals of Internal Medicine 1989110 526-531.

6 Stanley HL, Schmitt BP, Poses RM \& Deiss WP. Does hypogonadism contribute to the occurrence of a minimal trauma hip fracture in elderly men? Journal of the American Geriatric Society $199139766-771$.

7 Janowsky JS, Oviatt SK \& Orwoll ES. Testosterone influences spatial cognition in older men. Behavioral Neuroscience 1994108 325-332.

8 Wang C, Eyre DR, Clark R, Kleinberg D, Newman C, Iranmanesh A et al. Sublingual testosterone replacement improves muscle mass and strength, decreases bone resorption and increases bone formation markers in hypogonadal men. Journal of Clinical Endocrinology and Metabolism 199681 3654-3662.

9 Morley JE, Kaiser FE, Perry HM 3rd, Patrick P, Morley PM, Stauber PM et al. Longitudinal changes in testosterone, luteinizing hormone, and follicle-stimulating hormone in healthy older men. Metabolism: Clinical and Experimental 199746 410-413.

10 Veldhuis JD, Urban RJ, Lizarralde G, Johnson ML \& Iranmanesh A. Attenuation of luteinizing hormone secretory burst amplitude as a proximate basis for the hypoandrogenism of healthy aging men. Journal of Clinical Endocrinology and Metabolism 199275 707713.

11 Pincus SM, Mulligan T, Iranmanesh A, Gheorghiu S, Godschalk M \& Veldhuis JD. Older males secrete luteinizing hormone and testosterone more irregularly, and jointly more asynchronously, than younger males: dual novel facets. Proceedings of the National Academy of Sciences of the USA 199693 14100-14105.

12 Deslypere JP, Kaufman JM, Vermeulen T, Vogelaers D, Vandalem JL \& Vermeulen A. Influence of age on pulsatile luteinizing hormone release and responsiveness of the gonadotrophs to sex hormone feedback in men. Journal of Clinical Endocrinology and Metabolism $19876468-73$.

13 Whitcomb RW \& Crowley WF Jr. Hypogonadotropic hypogonadism: gonadotropin-releasing hormone therapy. Current Therapy in Endocrinology and Metabolism 19976 353-355.

14 Manni A, Pardridge WM, Cefalu W, Nisula BC, Bardin CW, Santner SJ \& Santen RJ. Bioavailability of albumin-bound testosterone. Journal of Clinical Endocrinology and Metabolism $198561705-710$.

15 Veldhuis JD, Rogol AD, Johnson ML \& Dufau ML. Endogenous opiates modulate the pulsatile secretion of biologically active luteinizing hormone in man. Journal of Clinical Investigation 1983 72 2031-2040.

16 Lambert-Messerlian GM, Hall JE, Sluss PM, Taylor AE, Martin KA, Groome NP Jr et al. Relatively low levels of dimeric inhibin circulate in men and women with polycystic ovarian syndrome using a specific two-site enzyme-linked immunosorbent assay. Journal of Clinical Endocrinology and Metabolism 199479 45-50.

17 Veldhuis JD \& Johnson ML. Cluster analysis: a simple, versatile and robust algorithm for endocrine pulse detection. American Journal of Physiology 1986250 E486-E493.

18 Pincus SM, Veldhuis JD, Mulligan T, Iranmanesh A \& Evans WS. Effects of age on the irregularity of LH and FSH serum concentrations in women and men. American Journal of Physiology 1997273 E989-E995.

19 Kaufman JM, Giri M, Deslypere JM, Thomas G \& Vermeulen A. Influence of age on the responsiveness of the gonadotropes to luteinizing hormone-releasing hormone in males. Journal of Clinical Endocrinology and Metabolism 1991 72 1255-1260.

20 Zwart AD, Urban RJ, Odell WD \& Veldhuis JD. Contrasts in the gonadotropin-releasing dose-response relationships for luteinizing hormone, follicle-stimulating hormone, and alphasubunit release in young vs older men: appraisal with highspecificity immunoradiometric assay and deconvolution analysis. European Journal of Endocrinology 1996135 399-406.

21 Snyder PJ, Reitano JF \& Utiger RD. Serum LH and FSH responses to synthetic gonadotropin-releasing hormone in normal men. Journal of Clinical Endocrinology and Metabolism $197541938-$ 945.

22 Harman SM, Tsitouras PD, Costa PT \& Blackman MR. Reproductive hormones in aging men. II. Basal pituitary gonadotropins and gonadotropin responses to luteinizing hormone-releasing hormone. Journal of Clinical Endocrinology and Metabolism 1982 54 547-551.

23 Celani MF, Montanini V, Baraghini GF, Carani C \& Marrama P. Effects of acute stimulation with gonadotropin-releasing hormone $(\mathrm{GnRH})$ on biologically active serum luteinizing hormone (LH) in elderly men. Journal of Endocrinological Investigation $19847589-$ 594.

24 Mulligan T, Iranmanesh A, Gheorghiu S, Godschalk M \& Veldhuis JD. Amplified nocturnal luteinizing hormone (LH) secretory 
bursts frequency with selective attenuation of pulsatile (but not basal) testosterone secretion in healthy aged men: possible Leydig cell desensitization to endogenous LH signaling - a clinica research center study. Journal of Clinical Endocrinology and Metabolism 199580 3025-3031.

25 Vermeulen A, Desslypere JP \& Kaufman JJ. Influence of antiopioids on luteinizing hormone pulsatility in aging men. Journal of Clinical Endocrinology and Metabolism 198968 68-72.

26 Winters SJ \& Troen P. Episodic luteinizing hormone (LH) secretion and the response of LH and follicle-stimulating hormone to LH-releasing hormone in aged men: evidence for coexistent primary testicular insufficiency and an impairment in gonadotropin secretion. Journal of Clinical Endocrinology and Metabolism $198255560-565$

27 Rosselli CE, Thornton JE \& Chambers KC. Age-related deficits in brain estrogen receptors and sexual behavior of male rats. Behavioral Neuroscience 1993107 202-209.

28 Romero MT, Silverman AJ, Wise PM \& Witkin JW. Ultrastructura changes in gonadotropin-releasing hormone neurons as a function of age and ovariectomy in rats. Neuroscience 199458 217-225.

29 Wise PM, Scarbrough K, Lloyd J, Cai A, Harney J, Chiu S et al. Neuroendocrine concomitants of reproductive aging. Experimental Gerontology 199429 275-283.

30 Huang HH, Kissane JQ \& Haawrylewicz EJ. Restoration of sexual function and fertility by fetal hypothalamic transplant in impotent aged male rats. Neurobiology of Aging 1987 8 465-472.

31 Arias P, Carbone S, Szwarcfarb B, Feleder C, Rodriguez M, Scacchi $\mathrm{P}$ et al. Effects of aging on N-methyl-D-aspartate (NMDA)-induced GnRH and LH release in female rats. Brain Research 1996740 234-238.

32 Liao C, Reaven E \& Azhar S. Age-related decline in the steroidogenic capacity of isolated rat Leydig cells: a defect in cholesterol mobilization and processing. Journal of Steroid Biochemistry and Molecular Biology 199346 39-47.

33 Deslypere JP \& Vermeulen A. Leydig cell function in normal men: effect of age, lifestyle, residence, diet and activity. Journal of Clinical Endocrinology and Metabolism 198459 955-962.

34 Mitchell R, Hollis S, Rothwell C \& Robertson WR. Age-related changes in the pituitary-testicular axis in normal men; lower serum testosterone results from decreased bioactive LH drive. Clinical Endocrinology 199542 501-507.

35 Marrama P, Montanini V, Celani MF, Carani C, Cioni K, Bazzani M et al. Decrease in luteinizing hormone biological activity/ immunoreactivity ratio in elderly men. Maturitas $19845223-$ 231.
36 Giusti M, Valenti S, Guido R, Cuttica CM, Foppiani L \& Giordano G. LH isoform profiles during short-term pulsatile LHRH administration in elderly men. Journal of Endocrinological Investigation $199720194-202$.

37 Veldhuis JD, Urban RJ, Beitins I, Blizzard RM, Johnson ML \& Dufau ML. Pathophysiological features of the pulsatile secretion of biologically active luteinizing hormone in man. Journal of Steroid Biochemistry 198933 739-750.

38 Madersbacher S, Stulnig T, Huber LA, Schonitzer D, Dirnhofer S, Wick $\mathrm{G}$ et al. Serum glycoprotein hormones and their free alphasubunit in a healthy elderly population selected according to the SENIEUR protocol. Analyses with ultrasensitive time resolved fluoroimmunoassays. Mechanisms of Aging and Development 1993 $71223-233$.

39 Veldhuis JD, Urban RJ \& Dufau ML. Differential responses of biologically active luteinizing hormone secretion in older versus young men to interruption of androgen negative feedback. Journal of Clinical Endocrinology and Metabolism 199479 17631770 .

40 Urban RJ, Veldhuis JD, Blizzard RM \& Dufau ML. Attenuated release of biologically active luteinizing hormone in healthy aging men. Journal of Clinical Investigation 198881 1020-1029.

41 Gruenewald DA, Naai MA, Hess DL \& Matsumoto AM. The Brown Norway rat as a model for male reproductive aging: evidence for both primary and secondary testicular failure. Journal of Gerontology 199449 B42-B50.

42 Grzywacz FW, Chen H, Allegretti J \& Zirkin BR. Does ageassociated reduced Leydig cell testosterone production in Brown Norway rats result from understimulation by luteinizing hormone? Journal of Andrology $199819625-630$.

43 Tenover JS, McLachlan RI, Dahl KD, Burger HG, deKretser DM \& Bremner WJ. Decreased serum inhibin levels in normal elderly men: evidence for a decline in Sertoli cell function with aging. Journal of Clinical Endocrinology and Metabolism 198867 455461.

44 Haji M, Tanaka S, Nishi Y, Yanase T, Takayanagi R, Hasegawa Y et al. Sertoli cell function declines earlier than Leydig cell function in aging Japanese men. Maturitas 199418 143-153.

45 Matt DW, Kauma SW, Pincus S, Veldhuis JD \& Evans WS. Characteristics of LH secretion in young versus older premenopausal women. American Journal of Obstetrics and Gynecology 1998 $178504-510$.

Received 8 February 1999

Accepted 10 May 1999 